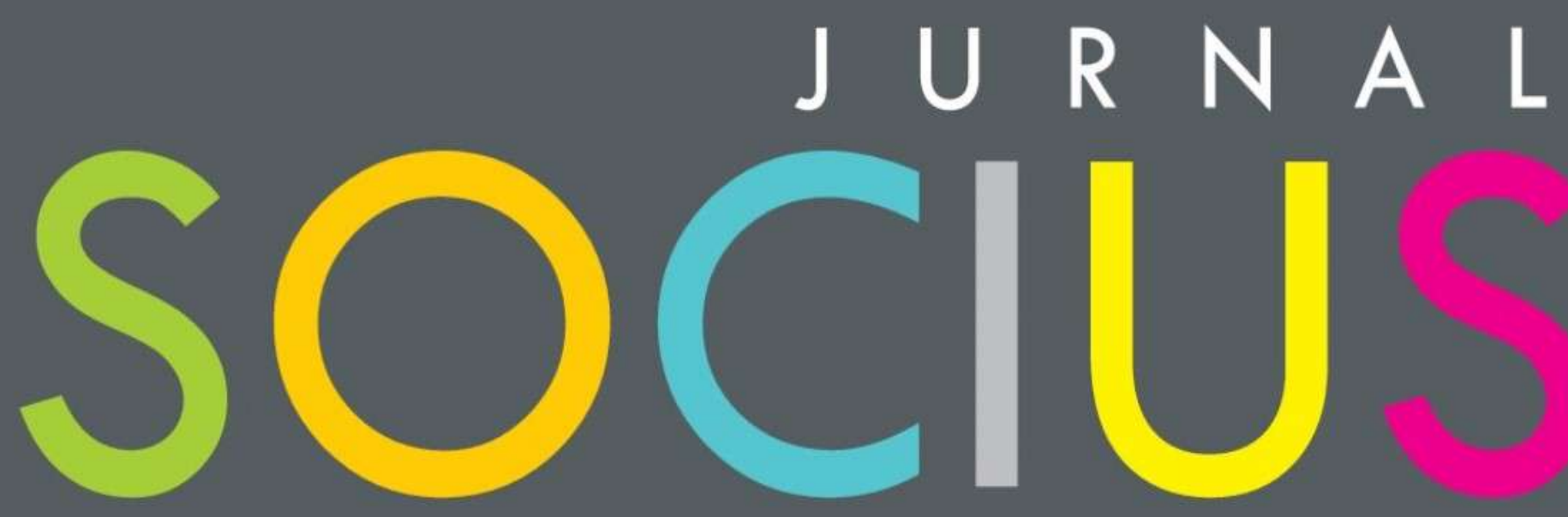

Journal of Sociology Research and Education

DITERBITKAN OLEH :

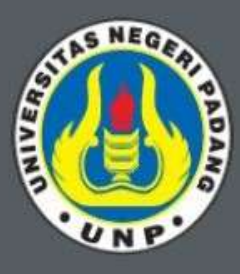

LABOR JURUSAN SOSIOLOGI FAKULTAS ILMU SOSIAL UNIVERSITAS NEGERI PADANG 


\section{SOCIUS}

Vol. 5, No.1, Th. 2018

ISSN : 2356-4180 (cetak)

2442-8663 (online)

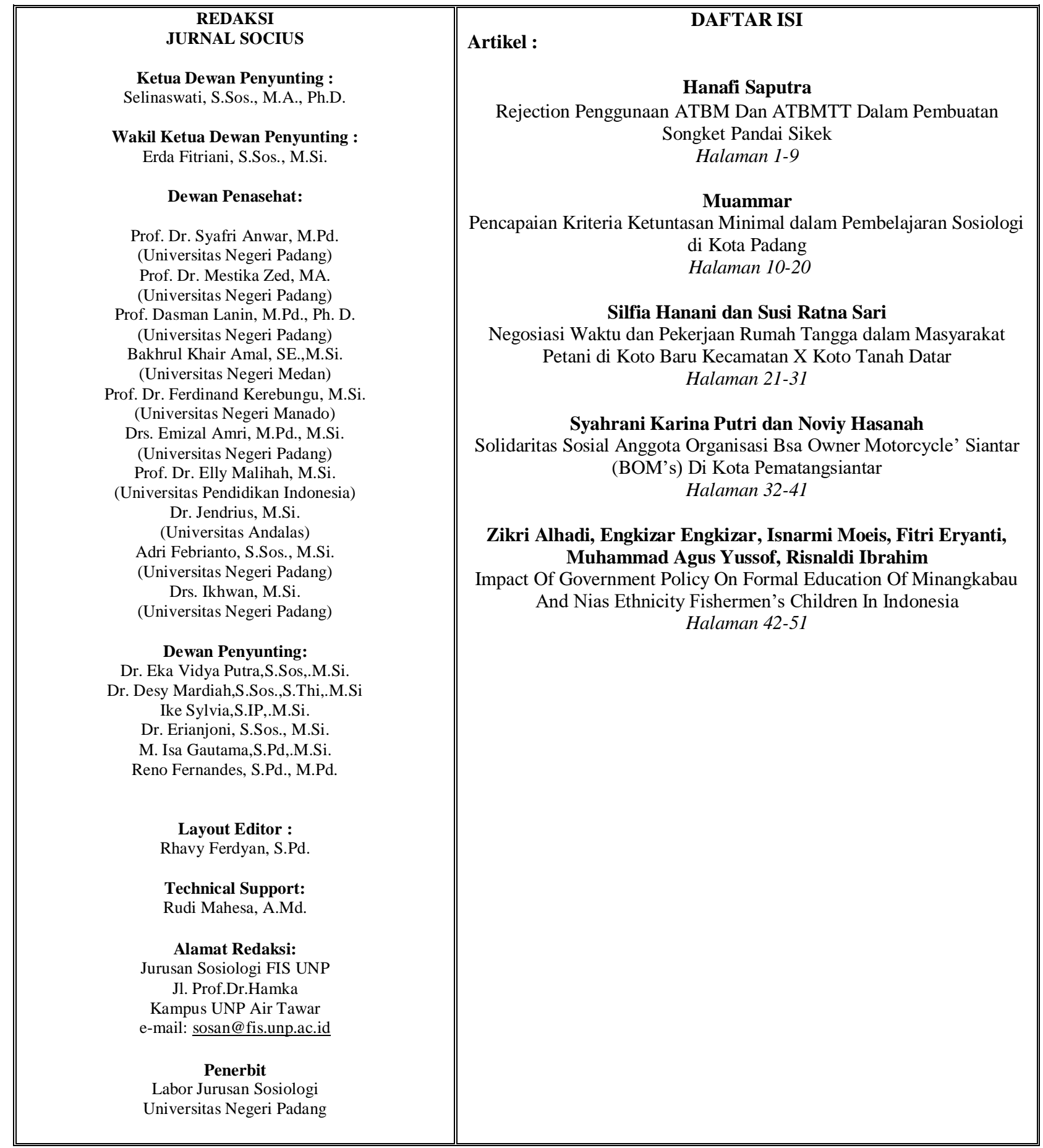




\title{
PENCAPAIAN KRITERIA KETUNTASAN MINIMAL DALAM PEMBELAJARAN SOSIOLOGI DI SMA KOTA PADANG
}

\author{
Muammar \\ Universitas Negeri Padang \\ email: muammaryes@gmail.com
}

\begin{abstract}
Abstrak
Artikel ini membahas tentang strategi pencapaian KKM dalam pembelajaran Sosiologi di SMA Kota Padang. KKM pada mata pelajaran Sosiologi yang ditetapkan di SMA Kota Padang tergolong tinggi, sedangkan dari segi ketercapaian rendah. Namun guru tetap mengusahakan nilai peserta didik mencapai KKM yang telah ditetapkan di sekolah. Dalam hal ini guru sebagai perencana dan imlementator memiliki strategi pencapaian yang berbeda-beda dalam pencapaian KKM. Strategi pencapaian KKM pada pembelajaran Sosiologi ditinjau dari proses pembelajaran, ketersediaan sumber belajar dan proses penilaian. Oleh karena itu, penelitian ini dianalisis dengan menggunakan teori struktural fungsional Talcoth Parsons yang dikenal dengan skema AGIL. Penelitian ini merupakan penelitian dengan pendekatan kualitatif deskriptif. Pemilihan informan dilakukan dengan pemilihan teknik purposive sampling dengan jumlah informan 29 orang. Pengumpulan data dilakukan dengan observasi, wawancara mendalam dan studi dokumentasi. Data yang telah terkumpul dilakukan triangulasi sumber dan dianalisis dengan mengacu pada model analisi Miles dan Huberman. Hasil penelitian ini menunjukkan bahwa strategi yang dilakukan dalam mencapai KKM dalam pembelajaran Sosiologi adalah pertama, guru memvisualisasikan model, metode dan media pembelajaran yang bervariasi untuk meningkatkan pemahaman peserta didik. Kedua, memfasilitas sumber belajar, dan menyediakan fasilitas yang mendukung proses pelaksanaan proses pembelajaran Sosiologi seperti proyektor, tv dan komputer. Ketiga, melakukan proses penilaian yang otentik, dimana guru melakukan penilaian sikap, pengetahuan, dan keterampilan. Dalam hal ini guru dan pihak sekolah menerapkan formula yang berbeda-beda agar tercapai KKM yang telah ditetapkan.
\end{abstract}

Kata Kunci: Kriteria Ketuntasan Minimal, Sistem, Strategi guru dan Pencapian

Abstract
This article discusses the strategy of achieving KKM Sociology learning in senior hight school Padang City. KKM on Sociology subject set in senior hight school Padang is high, while in terms of low achievement. However, the teacher still keeps the value of the students reaching the KKM that has been established in the school. In this case the teacher as planner and imlementator have different achievement strategies in achieving KKM. Strategy of KKM achievement in Sociology learning in terms of learning process, availability of learning resources and assessment process. Therefore, this study was analyzed using Talcott Parsons functional structural theory known as AGIL scheme. This research is a research with qualitative descriptive approach. The selection of informants was done by choosing purposive sampling technique with 29 informants. Data collection was done by observation, in-depth interview and documentation study. The data have been collected by triangulation of sources and analyzed with reference to analytical model of Miles and Huberman. The results of this study indicate that the strategy undertaken in achieving KKM in Sociology learning. First, the teacher visualizes the varied models, methods and learning media to improve learners' understanding. Second, facilitate learning resources, and provide facilities that support the process of implementing the Sociology learning process such as projector, tv and computer. Third, conduct an authentic assessment process, in which teachers conduct attitude, knowledge, and skill assessments. In this case teachers and schools apply different formulas to achieve the established KKM.

Keywords: KKM, System, Teacher Strategy and achievement

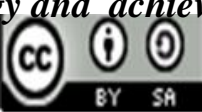

Received: March 8, 2018

Revised: April 4, 2018 Available Online: June 18, 2018

Jurnal Socius: Journal of Sociology Research and Education Vol. 5, No.1, Th. 2018

ISSN: Online 2442-8663 - Print 2356-4180

Copyright $\odot 2018$, Jurnal Socius 


\section{Pendahuluan}

Pembelajaran Sosiologi merupakan suatu proses yang memerlukan perencanaan secara seksama dan sistematis. Menurut Depdiknas (2008: 1) materi pembelajaran Sosiologi mencakup konsep dasar, pendekatan metode, teknik dan analisis dalam mengkaji berbagai fenomena dan berbagai permasalahan sosial yang ditemui dalam kehidupan nyata di masyarakat. Dalam materi pelatihan guru implementasi kurikulum 2013 ( 2014: 13) ditulis pembelajaran Sosiologi merupakan kajian mengenai berbagai peristiwa di masyarakat yang terkait dengan hubungan individu, individu dengan kelompok dan kelompok dengan kelompok. Selain itu, Sosiologi juga dapat dimaknai sebagai kajian penelitian secara ilmiah tentang interaksi sosial dan hasilnya yaitu organisasi sosial, termasuk tentang sistem sosial, dan bagaimana sistem tersebut mempengaruhi orang, dan sebaliknya bagaimana orang yang terlibat di dalamnya mempengaruhi sistem tersebut.

Mata pelajaran Sosiologi memiliki arti strategis dalam pembentukan watak dan peradaban yang bermartabat serta pembentukan manusia Indonesia yang memiliki rasa sosial yang tinggi. Tujuan pembelajaran Sosiologi berdasarkan kurikulum 2013 yaitu: pertama, membangun kesadaran peserta didik tentang pentingnya konsep masyarakat, terdiri dari berbagai sistem sosial, struktur sosial, kelompok sosial, organisasi sosial yang ditujukkan oleh realitas sosial dengan bentuk dan dinamikanya. Kedua, mengembangkan kemampuan berpikirdan kepekaan sosial (social thinking) yang menjadi dasar untuk kemampuan berpikir logis, kreatif, inspiratif, dan inovatif. Ketiga, menumbuhkan apresiasi dan penghargaan peserta didik untuk mendukung tertib sosial, dan menemukan alternatif pemecahan sosial dan keempat, menumbuhkembangkan kesadaran diri peserta didik sebagai bagian dari masyarakat, dan bangsa Indonesia yang memiliki rasa bangga dan cinta tanah air, melahirkan empati dan perilaku toleran yag dapat diimplementasikan dalam berbagai kehidupan masyarakat dan bangsa. Untuk mencapai tujuan tersebut, maka ditetapkan kriteria ketuntasan minimal (KKM).

Menurut Permendikbud No 23 tahun 2016 tentang Standar Penilaian Pendidikan menyatakan bahwa, KKM adalah kriteria ketuntasan belajar yang ditentukan oleh satuan pendidikan yang mengacu kepada standar kompetensi kelulusan, dengan mempertimbangkan karakteristik peserta didik, karakteristik mata pelajaran, dan kondisi satuan pendidikan.

Penetapan KKM di dalam pembelajaran Sosiologi menyebabkan terdapatnya perbedaan KKM yang berlaku di beberapa SMA di kota Padang. Berdasarkan data yang penulis peroleh KKM adalah berada di angka 80, 81, dan

82. Penetapan angka KKM yang ditetapkan tergolong tinggi apabila dilihat dari sistem penilaian kurikulum 2013, maka nilai terendah peserta didik dalah $\mathrm{B}+$, sedangkan segi pencapaian peserta didik rendah. Namun guru tetap mengusahakan agar nilai peserta didik tetap mencapai angka KKM yang telah ditetapkan.

Berdasarkan fakta dan temuan penulis, penulis merasa tertarik untuk meneliti pencapaian KKM dalam pembelajaran Sosiologi di SMA kota Padang. Hal dikarenakan penulis berpandangan bahwa ada beberapa faktor yang menarik untuk dikaji dalam proses dalam pencapaian KKM pada pembelajaran Sosiologi. Dalam hal ini guru sebagai perencana dan implementator memiliki strategi pencapaian yang berbeda-beda dalam pencapaian KKM. Strategi pencapaian KKM pada pembelajaran Sosiologi ditinjau dari proses pembelajaran, ketersediaan sumber belajar, dan proses penilaian.

Fokus kajian di dalam penelitian ini adalah mendeskripsikan strategi yang dilakukan oleh guru agar peserta didik dapat mencapai KKM pada pembelajaran Sosiologi di SMA kota Padang. Guru sebagai perencana dan implementator memiliki strategi pencapaian yang 
berbeda-beda dalam pencapaian KKM. Strategi pencapaian KKM pada pembelajaran Sosiologi ditinjau dari proses pembelajaran, ketersediaan sumber belajar dan proses penilaian.

Permasalahan di atas dianalisis dengan menggunakan teori struktural fungsional Talcott Parsons. Fungsi menurut Parsons adalah kumpulan kegiatan yang ditujukan ke arah pemenuhan kebutuhan tertentu atau kebutuhan sistem. Parsons yakin ada 4 fungsi penting yang dilakukan semua sistem yaitu AGIL. Secara bersama-sama ke empat imperatif funngsional ini dikenal dengan skema AGIL. AGIL merupakan akronik dari Adaptation, Goal Attainment, Integration, dan Latency atau Latern Pattern-Maintance (Ritzer, 2007: 121-123).

\section{Metodologi Penelitian}

Penelitian ini dilakukan di SMA N 1 Padang, SMA N 12 Padang dan SMA Pembangunan Laboratorium UNP selama kurang lebih 3 bulan yaitu dari Mei sampai Juli 2017. Dilihat dari pendekatannya penelitian ini adalah penelitian kualitatif deskripstif. Pemilihan informan dilakukan dalam penelitian ini adalah secara purposive sampling dengan jumlah informan 29 orang. Informan penelitian ini adalah guru mata pelajaran Sosiologi, kepala sekolah, wakil kurikulum, mahasiswa yang melaksanakan praktek lapangan kependidikan, dan peserta didik.

Pengumpulan data dilakukan dengan melakukan observasi, wawancara mendalam dan studi dokumentasi. Data yang diperoleh dianalisis dengan menggunakan model analisis Miles dan Huberman dengan menggunakan langkah- langkah pengumpulan data, reduksi data, penyajian data, kesimpulan dan laporan hasil penelitian.

\section{Strategi Guru Dalam Pencapaian KKM}

\section{Melakukan Proses Pembelajaran yang Bervariasi}

Sekolah melakukan proses pembelajaran dengan menerapkan model, metode dan media pembelajaran yang bervariasi untuk meningkatkan pemahaman peserta didik dalam memahami materi pembelajaran.

Model yang digunakan oleh guru mata pembelajaran Sosiologi di SMA N 1 Padang adalah number head together, bermain peran, problem based learning, mencari pasangan, dan discovery learning. Penggunaan model pembelajaran juga diintegrasikan dengan metode mengajar yang relevan. Model pembelajaran yang digunakan adalah metode diskusi, ceramah, demonstrasi dan penugasan. Selain itu juga diintegrasikan dengan metode mengajar yang bervariasi yaitu metode diskusi, ceramah, penugasan, dan demonstrasi.

Implementasi model pembelajaran dan metode mengajar di dukung dengan penggunaan media pembelajaran guna untuk meningkatkan pemahaman peserta didik terhadap mata pelajaran Sosiologi. Adapun media yang digunakan di SMA N 1 Padang adalah slide powerpoint, video, dan chart.

Hal yang sama juga terjadi di SMA N 12 Padang bahwa Sekolah ini juga menggunakan model pembelajaran yang bervariasi salah satunya adalah modelpembelajaran STAD (Student Team Acievment Division). Penggunaan model ini dapat menarik minat peserta didik. Selain guru menuntut peserta didik untuk aktif, inovasi yang dilakukan guru dengan menerapkan sistem point dan diumumkan kelompok terbaik di dalam pembelajaran. Akumulasi di setiap pertemuan disampaikan dan akhir pembelajaran akan diumumkan kelompok pemenang. Kemudian kelompok pemenang akan memperoleh hadiah dari kelompok lain. 
Strategi untuk mencapai KKM dengan menciptakan pembelajaran yang menarik minat peserta didik terhadap mata pelajaran. Hal ini dapat dilakukan dengan menggunakan model pembelajaran yang inovatif, dan kreatif penggunaannya agar peserta didik tidak merasa bosan. Upayanya dengan menggunakan model pembalajaran yang menarik. Adapun model pembelajaran yang digunakan adalah number head together, bermain peran, mencari pasangan, STAD (Student Team Achievment Division) dan discoveru learning. Model pemelajaran yang diaplikasikan memiliki kaitan yang erat dengan metode mengajar seperti diskusi, kelompok, ceramah, penugasan, dan demonstrasi.

Penerapan model pembelajaran dan metode mengajar tidak harus berpusat kepada guru. Peserta didik juga menyampaikan dan mendiskusikan di dalam kelas. Tugas guru mengamati, mengarahkan, jalannya proses diskusi dan untuk mengukur pencapaian tujuan pembelajaran diberikan tugas atau kuis di akhir pembelajaran. Oleh karena itu dapat disimpulkan bahwa di SMA N 12 Padang bahwa untuk mencapai KKM, strategi yang digunakan adalah menciptakan proses pembelajaran yang bervariasi agar dapat menarik minat peserta didik terhadap pembelajaran Sosiologi. Hal ini dapat terwujud dengan menggunakan model pembalajaran, dan metode mengajar yang bervariasi.

Dalam pemilihan ini dengan memperhatikan materi dan karakteristik peserta didik agar tujuan pembelajaran dapat tercapai dengan baik. Upaya dalam pencapaian KKM, guru juga menggunakan media pembelajaran sebagai alat bantu dalam proses pembelajaran. Adapun media yang digunakan adalah gambar, peta konsep, slide powerpoint, namun terkadang masih terkendala oleh kurangnya ketersediaan proyektor yang dimiliki oleh sekolah.

Strategi pencapaian KKM yang berbeda terjadi di SMA Laboratorium Pembangunan UNP. Dalam upaya pencapaian KKM dalam pembelajaran Sosiologi guru mengupayakan menggunakan model pembelajaran yang bervariasi. Namun dengan kemampuan, karakteristik, dan kesadaran belajar peserta didik yang masih agak rendah. Hal ini mengharuskan proses pembelajaran berpusat kepada guru. Adapun metode mengajar yang efektif adalah metode ceramah, tanya jawab, dan penugasan.

Berdasarkan pengamatan dan wawancara yang penulis lakukan dapat disimpulkan, bahwa stategi yang dilakukan guru di SMA kota Padang dalam mencapai KKM adalah dengan memvisualisasikan model, metode, dan media pembelajaran. Hal ini dilakukan untuk menciptakan proses pembelajaran yang aktif, dan bermakna dalam rangka meningkatkan pemahaman peserta didik.

\section{Menyediakan sumber dan fasilitas belajar}

Sumber belajar merupakan salah satu faktor penentu keberhasilan pencapaian KKM dalam pembelajaran Sosiologi. Jenis sumber belajar adalah ketersediaan di perpustakaan dan media pendukung proses pembelajaran.

Ketersediaan buku di SMA N 1 Padang untuk mata pelajaran Sosiologi bahwa jumlah buku yang tersedia masih mengalami kekurangan untuk diperoleh masing-masing peserta didik. Kekurangan buku terdapat pada kelas XI dan XII, sedangkan untuk kelas X cukup dan bahkan melebihi dari jumlah peserta didik.

Kekurangan buku ini diakibatkan oleh perubahan kurikulum, dan anggaran dana sekolah yang belum mampu melengkapi kebutuhan buku sebagai sumber belajar. Strategi yang dilakukan adalah guru mencari terbitan PENA yang harganya terjangkau oleh semua peserta didik. Selain itu juga sekolah memberikan fasilitas layanan internet, dan memperbolehkan layanan untuk diakses sebagai sarana bagi peserta didik untuk menambah referensi yang relevan dalam proses belajar mengajar. 
Hal yang tidak jauh berbeda juga terjadi di SMA N 12 Padang bahwa kondisi perpustakaan sekolah dalam kondisi baik. Fasilitas seperti meja belajar, dan kipas angin tersedia untuk mendukung suasana belajar. Ketersediaan buku sebagai sumber belajar cukup lengkap untuk mata pelajaran Sosiologi cukup lengkap, dan hanya terdapat kekurangan untuk kelas X. Kekurangan persediaan buku mata pelajaran Sosiologi di SMA N 12 Padang. Kondisi ini dikarenakan perubahan yang terjadi pada kurikulum dan keterbatasan anggaran yang dimiliki sekolah untuk pembelian buku. Fasilitas untuk melengkapi kekurangan sebenarnya tersedia di sekolah seperti layanan internet, namun belum diperbolehkan untuk diakses oleh peserta didik. Hal dikarenakan sekolah beranggapan peserta didik belum mampu memanfaatkannya dengan bijaksana. Strategi yang dilakukan guru adalah dengan memperbolehkan peserta didik untuk mengcopy buku, meminjam kepada teman dan mengakses internet menggunakan smartphone untuk membantu ketersedaian sumber belajar.

Hal yang berbeda terjadi di SMA Pembangunan UNP bahwa memiliki fasilitas yang bagus. Mulai dari ketersediaan buku dan komputer yang bias diakses langsung oleh peserta didik untuk mencari bahan mata pelajaran. Dengan jumlah buku yang memadai setiap peserta didik diperbolehkan untuk melakukan peminjaman selama satu tahun. Selain itu dalam mempermudah mencari referensi, sekolah juga menyediakan komputer yang terkoneksi dengan internet yang bisa diakses langsung oleh peserta didik.

Berdasarkan pengamatan dan analisa penulis, bahwa ketersediaan sumber belajar juga dipengaruhi oleh input peserta didik. Rendahnya input peserta didik membuat sekolah berusaha menyediakan, dan memberikan fasilitas yang lengkap dan memadai untuk mendukung proses pembelajaran dalam rangka pencapaian KKM mata pelajaran.

Input peserta didik dipengaruhi oleh jalur seleksi penerimaan peserta didik. Seleksi peserta didik di SMA N 1 Padang melakukan beberapa tahapan jalur seleksi. Pertama, seleksi mandiri. Jalur mandiri adalah seleksi yang dilakukan dengan melaksanakan ujian tertulis sebagai cara penerimaan peserta didik. Persentase peserta didik yang diterima melalui jalur seleksi mandiri adalah $75 \%$. Kedua, melalui jalur prestasi, jalur prestasi yang dimaksud adalah melalui prestasi tahfidz Al-qur'an dan olahraga. Persentase peserta didik yang diterima melalui jalur prestasi adalah $15 \%$. Terakhir adalah jalur akademik yaitu bagi peserta didik yang memiliki prestasi akademik yang baik di sekolah menengah pertama. Persentase peserta didik yang diterima melalui jalur akademik adalah $10 \%$.

Sedangkan proses penerimaan peserta didik yang terjadi di SMA N 12 Padang bahwa penerimaan peserta didiknya bekerjasama dengan Dinas Pendidikan Kota Padang. sistem penerimaan yang digunakan adalah sistem rayon. Sistem rayon yang digunakan ada 4 jenis rayon dengan masing-masing persentase penerimaan persentase peserta didik. Adapun jenis rayon yang digunakan adalah rayon sekolah $85 \%$, rayon kota $7 \%$, rayon provinsi $5 \%$, dan $3 \%$.

Hal yang berbeda juga terjadi di SMA Pembangunan UNP bahwa proses penerimaan peserta didik baru biasanya dilakukan dengan menggunakan 3 jalur seleksi masuk yaitu pertama jalur prestasi, yaitu peserta didik yang memiliki prestasi akademik sewaktu di SMP yang memperoleh peringkat 10 di sekolahnya. Namun jumlahnya sedikit, hanya berjumlah 20 orang peserta didik. Kedua, jalur LWS (Lingkup Warga Sekolah) yaitu berdasarkan rayon, anak guru, dan anak karyawan serta dosen UNP langsung diterima untuk melanjutkan pendidikan di SMA Pembangunan UNP. Ketiga, melalui seleksi NEM hasil ujian nasional.

Berdasarkan hasil penelitian menunjukkan bahwa ketersediaan sumber belajar memiliki perbedaan fasilitas yang disediakan oleh sekolah sebagai pendukung pembelajaran di SMA Negeri dan SMA Swasta. Fasilitas yang disediakan terkhusus pada buku sebagai sumber belajar dan proyektor sebagai alat bantu untuk menampilkan media pembelajaran. 
Kondisinya adalah bahwa ketersediaan sumber belajar dan sumber daya dukung pembelajaran di SMA Swasta tersedia secara lengkap, baik berupa buku sebagai sumber belajar, maupun proyektor sebagai alat bantu media pembelajaran. Hal ini dilakukan sebagai upaya untuk meningkatkan input peserta didik yang rendah, jika dibandingkan dengan SMA Negeri. Hal sebaliknya terjadi di SMA Negeri bahwa masih terdapat kekurangan fasilitas belajar mulai buku dan proyektor, tetapi mampu mencapai KKM karena di dukung oleh faktor input peserta didik yang baik.

\section{Melakukan Proses Penilaian yang Otentik}

Penilaian merupakan proses pengumpulan dan pengolahan penilaian hasil belajar. Penilaian hasil belajar peserta didik mencakup sikap, pengetahuan, dan keterampilan yang dilakukan secara berimbang sehingga dapat digunakan untuk menentukan posisi relatif setiap peserta didik terhadap standar yang telah ditetapkan.

Penilaian mata pelajaran Sosiologi di SMA N 1 Padang bahwa 3 jenis penilaian yaitu penilaian kognitif, penilaian psikomotor, dan penilaian afektif. Penilaian dilakukan berupa tes tulis dan penugasan. Instrumen tes tertulis biasanya menggunakan pilihan ganda, dan essay dalam ulangan harian. Sedangkan instrumen penugasan berupa pekerjaan rumah baik individu maupun kelompok. Bobot soal untuk mengukur kemampuan kognitif peserta didik adalah $30 \%$ soal mudah, $40 \%$ soal sedang, dan $30 \%$ soal sulit.

Strategi pencapaian KKM tidak hanya dipengaruhi oleh proses pembelajaran, penilaian juga menjadi faktor yang menentukan ketercapaian peserta didik. Penilaian akhir peserta didik di SMA N 1 Padang lebih menekankan kepada proses pembelajaran. Adapun point penting penilaian adalah nilai ulangan harian, ujian tengah semester, dan ujian akhir semester. Nilai ulangan harian termasuk di dalamnya tugas, ulangan, kuis, dan lain sebagainya. Adapun fomulasi penilaian akhir di SMA N 1 Padang adalah:

Rumus NA $=\frac{30 \% \mathrm{UH}+10 \mathrm{UTS}+10 \% \mathrm{UAS}}{5}$

Proses penilaian yang berbeda terjadi di SMA N 12 Padang bahwa bobot soal yang digunakan mempertimbangkan kompetensi dasar dan kompleksitas materi yang akan diujikan. Bobot soal yang digunakan tergantung instrumen penilaian yang digunakan di dalam penilaian ulangan harian. Kalau seandainya soal objektif, lebih banyak menggunakan soal yang sulit, dan kalau soalnya essay, bobot soal yang digunakan mudah dan sedang. Penentuan ini dengan berpedoman kepada teori ahli belajar yaitu Anderson, tetapi yang digunakan hanya pada tahap berpikir C3.

Secara keseluruhan bobot soal yang digunakan untuk mengukur kemampuan peserta didik adalah $30 \%$ soal mudah, $50 \%$ soal sedang, dan $20 \%$ soal sulit. Sedangkan penilaian psikomotor dilakukan melalui proses diskusi yaitu kemampuan presentasi, bertanya, menjawab pertanyaan dan hasil kerja kelompok berupa media presentasi yang ditampilkan. Selanjutnya penilaian afektif yaitu melalui jurnal.

Adapun kategori penilaian untuk melihat ketercapaian peserta didik yaitu dengan mengacu kepada pencapaian nilai ulangan harian, nilai ujian tengah semester dan nilai ujian akhir semester. Rumus yang digunakan adalah:

Rumus NA $=\frac{50 \cdot \mathrm{UH}+25 . \mathrm{UTS}+25 . \mathrm{UAS}}{100}$

Jurnal Socius Vol. 5, No.1, Th. 2018

ISSN: Online 2442-8663 - Print 2356-4180 
Hal yang berbeda juga terjadi di SMA Pembangunan UNP. Penetapan bobot soal yang dipakai dalam melihat ketercapaian peserta didik terhadap materi pembelajaran adalah berdasarkan kompleksitasnya. Selain itu juga dengan memperhatikan intek peserta didik. bobot soal yang digunakan adalah tergantung kepada jenis instrumen. Namun biasanya adalah $60 \%$ soal mudah, $30 \%$ sedang, dan $10 \%$ sulit. Peserta didik di SMA Pembangunan UNP pada mata pelajaran Sosiologi untuk soal dalam bentuk analisis masih mengalami kesulitan, oleh karenanya C3 masih sedikit digunakan. Cara penilaian peserta didik di SMA Pembangunan UNP adalah dengan mengkalkulasikan perolehan peserta didik pada ulangan harian, nilai ujian tengah semester, dan ujian akhir semester. Adapun rumus yang digunakan adalah:

$$
\text { Rumus NA }=\frac{70 . \mathrm{UH}+10 \cdot \mathrm{UTS}+20 \% \mathrm{UAS}}{100}
$$

Berdasarkan hasil penelitian menunjukkan bahwa penilaian yang dilakukan di SMA kota Padang memiliki jenis bobot soal dan formulasi penilaian yang berbeda-beda. Persentase penilaian tertinggi di SMA kota Padang adalah nilai ulangan harian yang termasuk di dalamnya nilai tugas, keaktifan, diskusi, dan ulangan. Sedangkan nilai ujian tengah semester dan ujian akhir semester memiliki persentase yang rendah. Kebijakan ini diambil agar proses penilaian lebih menekankan kepada proses pembelajaran.

Berdasarkan pengolahan rumus nilai akhir sekolah tersebut dapat diambil sebuah kesimpulan bahwa SMA Pembangunan UNP menggunakan rumus yang lebih efektif dalam membantu peserta didiknya memperoleh angka yang lebih tinggi jika dibandingkan di SMA Negeri yaitu SMA N 1 Padang dan SMA N 12 Padang. Selain menggunakan rumus yang mendukung peserta didik untuk mencapai KKM, guru mata pelajaran Sosiologi juga melakukan remedial bagi peserta didik yang tidak tuntas dalam pembelajaran Sosiologi. Remedial dilakukan dalam bentuk ujian ulang dan pemberian tugas kepada peserta didik.

Dalam proses penilaian setelah dilakukan ujian ulang dan remedial, namun masih terdapat peserta didik yang tidak tuntas dalam pembelajaran. Langkah terkahir yang dilakukan guru adalah melakukan pengangkatan pada nilai peserta didik. hal ini dilakukan guru berdasarkan kajian pendidikan seperti masa depan anak, kelulusan di SNMPTN, dan akreditasi sekolah.

\section{Pembahasan}

Guru adalah orang yang profesional di bidangnya, artinya tugas guru tidak bisa digantikan oleh orang lain, oleh sebab itu guru tidaklah semudah yang dibayangkan. Guru bukan hanya berdiri di kelas untuk memberikan materi atau bahan pelajaran, akan tetapi lebih dari itu peranan gurusangat menentukan keberhasilan peserta didik dalam proses pendidikan. Salah satunya adalah pencapaian kriteria ketuntasan minimal dalam pembelajaran yang ditetapkan oleh guru di sekolah.

Pencapaian kriteria ketuntasan minimal tidak hanya ditentukan oleh kemampuan peserta didik, namun tenaga pengajar, dan fasilitas di dalam belajar memiliki peranan dalam pencapaiannya. Strategi yang dilakukan guru merupakan pola umum rencana interaksi antara peserta didik dengan guru, dan sumber belajar lainnya pada lingkungan belajar untuk mencapai tujuan pembelajaran. Salah satu peranan guru adalah strategi yang digunakan berupa model, fasilitas sumber pendukung pembelajaran.

Dalam pencapaian KKM di beberapa sekolah di SMA kota Padang ditemukan bahwa setiap sekolah memiliki KKM yang berbeda-beda, hal ini diperoleh berdasarkan hasil analisis guru, baik dari segi kompleksitas materi, sumber daya dukung pembelajaran, dan 
intek peserta didik. Cara pencapaian secara umum yang digunakan guru dalam mencapai KKM adalah menggunakan model, metode mengajar yang bervariasi, sumber belajar dan media pembelajaran yang aplikatif.

Guru perlu menumbuhkembangkan motivasi belajar peserta didik untuk memperoleh hasil yang optimal. Menurut Sandjaya (2011: 29) ada beberapa hal yang bisa dilakukan guru dalam menumbuhkembangkan motivasi belajar siswa.

1. Memperjelas tujuan yang hendak dicapai

2. Membangkitkan minat siswa

3. Menciptakan suasana yang menyenangkan di dalam belajar

4. Memberikan pujian yang wajar terhadap setiap keberhasilan siswa

5. Memberikan penilaian

6. Berilah komentar terhadap hasil kerja peserta didik

7. Menciptakan persaingan dan kerjasama

Dengan demikian, proses belajar mengajar akan tercipta interaksi yang edukatif. Interakasi edukatif adalah suatu proses yang mengandung sejumlah norma dan sebuah gambaran hubungan aktif antara guru dan peserta didik yang berlangsung di dalam ikatan pendidikan.

Pencapaian KKM dalam pembelajaran tidak hanya ditentukan oleh proses pelaksanaan pembelajaran, tetapi juga dipengaruhi proses penilaian hasil belajar. Penilaian merupakan proses pengumpulan dan pengolahan informasi untuk mengukur pencapaian hasil belajar peserta didik. Strategi yang dilakukan sekolah di dalam penilaian adalah memberikan bobot yang tinggi pada nilai ulangan harian, melakukan remedial dan menambahkan nilai peserta didik agar mencapai ketuntasan belajar sesuai dengan KKM yang telah ditetapkan. Berdasarkan Permendikbud no 22 tahun 2016 mengenai penilaian hasil belajar (2016: 9) prosedur penilaian hasil belajar dilakukan pendidik dengan urutan:

Menetapkan tujuan penilaian dengan mengacu pada RPP yang disusun

1. Menyusun kisi-kisi penilaian

2. Membuat instrument penilaian berikut pedoman penilaian

3. Melakukan analisis kualitas instrumen

4. Melakukan penilaian

5. Mengolah, menganalisis, dan menginterpretasikan hasil penilaian

6. Melaporkan hasil penilaian

7. Memanfaatkan laporan hasil penilaian

Sistem penilaian yang diterapkan di SMA kota Padang adalah proses penilaian yang menekankan kepada proses dengan melihat keikutsertaan peserta didik di dalam pembelajaran. Dalam hal ini dapat disimpulkan bahwa sistem penilaian yang diciptakan mendukung peserta didik agar memperoleh nilai yang tinggi.

Talcott Parsons mengemukakan dalam aliran teori struktural fungsional yang dikenal dengan skema AGIL. Suatu fungsi adalah kumpulan kegiatan yang ditujukan ke arah pemenuhan kebutuhan tertentuatau kebutuhan sistem. Menurut Parsons ada 4 fungsi penting yang dilakukan oleh semua sistem yaitu AGIL. AGIL merupakan akronim dari Adaptation, Goal Attaintment, Integration, Latency atau Latern Pattern-Maintence (Ritzer, 2007: 121).

Sesuai dengan teori Talcoth Parsons di atas, strategi pencapaian KKM memerlukan kumpulan kegiatan untuk pemenuhannya. Kegiatan ini mulai dari perencanaan pembelajaran, pelaksanaan proses pembelajaran, dan penilaian pembelajaran.

Analisa peneliti adalah bahwa penetapan KKM perlu disosialisasikan kepada peserta didik, dan strategi pencapaian KKM perlukan proses adaptasi melalui proses pembelajaran berupa visualisasi model, metode dan media pembelajaran, ketersediaan sumber belajar 
untuk meningkatkan pemahamanan peserta didik, proses penilaian, dan formulasi penilaian. Hal ini merupakan wujud sistem yang diciptakan dan fungsional satu sama lain yang bertujuan untuk mencapai KKM yang ditetapkan oleh guru dalam mata pelajaran Sosiologi.

Sistem sosial menanggulangi fungsi integrasi dengan mengendalikan bagian- bagian yang menjadi komponennya. Sistem juga melaksanakan fungsi sebagai pemeliharaan pola dengan menyediakan aktor seperangkat norma dan nilai yang menjadi motivasi di dalam bertindak. Sekolah sebagai organisasi sosial di dalamnya terdapat sistem yang saling berkaitan satu sama lain yang memiliki status dan peran yang berbeda. Seperti halnya pencapaian KKM mata pelajaran Sosiologi di sekolah bahwa jika guru menjalankan peran, tugas dan tanggungjawabnya sebagai pendidik, maka akan berpengaruh terhadap substansi pencapaian KKM yang sesungguhnya.

Aliran struktural fungsional dari Parsons berangkat dari sebuah asumsi, bahwa masyarakat sebagai suatu sistem yang terdiri dari bagian-bagian yang saling berhubungan, dan fungsional antara satu dengan yang lainnya. Pencapaian KKM pada mata pelajaran Sosiologi dapat tercapai, jika setiap komponen saling berhubungan seperti guru, kepala sekolah, wakil kurikulum, wakil saran dan prasarana, peserta didik, dan sumber belajar diatur dan didikung dalam sistem pencapaiannya.

Dalam sistem AGIL Parsons mengatakan bahwa sebuah sistem harus menanggulangi situasi eksternal yang gawat, sistem menyesuaikan diri dengan lingkungan, dan menyesuaikan dengan kebutuhan, jika dikaitkan dengan strategi pencapaian KKM di sekolah menengah atas kota Padang yang berperan dalam proses adaptasi disini adalah pihak sekolah. Kepemimpinan kepala sekolah dan wakil kurikulum adalah cara atau usaha mereka dalam mendorong, membimbing, mengarahkan, memotivasi, menggerakkan guru, peserta didik untuk bekerjasama dan berperan serta guna mencapai tujuan pembelajaran dan pencapaian KKM. Dalam pencapaian KKM dalam pembelajaran Sosiologi di sekolah menengah atas kota Padang bahwa sekolah melakukan pelaksanaan pencapaian KKM yang berbeda-beda dengan membuat sistemnya masing- masing yang sesuai dengan kebutuhan dan kondisi peserta didik. Dengan demikian dapat disimpulkan bahwa sistemlah yang mengatur pencapaian peserta didik terhadap KKM.

\section{Implikasi}

Berdasarkan hasil penelitian di atas, dapat diketahui bahwa guru Sosiologi di beberapa sekolah menengah atas kota Padang melakukan strategi pencapaian yang bervariasi. Hal ini dapat dilihat dari strategi mengajar dalam proses pembelajaran yaitu dengan menggunakan model pembelajaran, metode mengajar, dan media pembelajaran yang berbeda. Implementasi model, metode, dan media disesuaikan dengan memperhatikan kompleksitas materi dan karakteristik peserta didik.

Pencapaian KKM juga dipengaruhi oleh faktor daya dukung yaitu ketersediaan sumber belajar. Berdasarkan hasil penelitian menunjukkan bahwa di SMA N 1 dan SMA N 12 Padang Masih mengalami kekurangan ketersediaan sumber belajar, sedangkan di SMA Pembangunan kesersediaan buku sebagai sumber belajar untuk masing-masing peserta didik.

Selain itu, di dalam prosedur penilaian setiap sekolah menggunakan bobot formulasi nilai akhir yang berbeda- beda. Formulasi penilaian akhir SMA N 1 Padang dengan rumus $30 \%$ nilai ulangan harian $+10 \%$ ujian tengah semester $+10 \%$ nilai ujian akhir semester di bagi 5. Berbeda dengan di SMA N 12 Padang dengan pola rumus yang berbeda-beda. 50\% nilai ulangan harian $+25 \%$ ujian tengah semester $+25 \%$ nilai ujian akhir semester dibagi 100. Hal yang berbeda juga terjadi di SMA Pembangunan UNP bahwa rumus nilai akhirnya adalah $70 \%$ nilai ulangan harian $+20 \%$ nilai ujian tengah semester $+10 \%$ nilai ujian akhir 
semester. Dari hal ini dapat disimpulkan bahwa setiap sekolah lebih menekankan kepada nilai ulangan yang paling tinggi.

Proses pembelajaran akan tercapai jika guru dapat meningkatkan motivasi peserta didik di dalam belajar karena dengan begitu peserta didik akan terdorong untuk berprestasi, melakukan sesuatu yang karena ketidakpuasan dengan hal yang didapat. Guru hendaknya memahami karakter peserta didik, dan guru tidak dapat memaksa atau menuntut peserta didik dapat sesuai dengan yang diharapkan. Tugas guru adalah menjaga, mengarahkan, dan membimbing agar peserta didik dapat berkembang sesuai dengan potensi, bakat, dan minatnya. Sebagai seorang guru harus memiliki referensi yang lebih banyak dibandingkan peserta didik. Hal ini bertujuan agar guru lebih memiliki pemahaman yang baik dari pada peserta didik. Dalam proses pembelajaran guru perlu memahami berbagai jenis media, dan sumber belajar serta mampu mengorganisasikannya dengan model pembelajaran yang relevan sesuai dengan peserta didik di sekolah. Dengan demikian proses pembelajaran akan lebih menyenangkan dan KKM dapat tercapai dengan baik.

\section{Penutup}

Dalam pencapaian KKM pada pembelajaran Sosiologi di SMA kota Padang, terdapat beberapa strategi yang dilakukan guru dalam proses pencapaiannya. Pertama, menggunakan model, metode, dan media pembelajaran yang bervariasi untuk meningkatkan pemahaman peserta didik. Kedua, menyediakan sumber, dan fasilitas belajar sebagai pendukung proses pembelajaran sebagai upaya mencapai KKM. Ketiga, melakukan penilaian otentik dengan melakukan 3 jenis penilaian yaitu penilaian sikap, pengetahuan dan keterampilan. Penilaian sikap dengan melakukan observasi dan jurnal. Sedangkan penilaian pengetahuan dilakukan dengan tes tertulis dan penugasan. Kemudian penilaian psikomotor dengan melihat kinerja dalam diskusi seperti presentasi dan tanya jawab. Sistem penilaian akhir di SMA kota Padang memiliki formulasi penilaian yang berbeda-beda, agar peserta didik dapat mencapai KKM yang telah di tetapkan guru mata pelajaran. Langkah selanjutnya yang dilakukan guru apabila peserta didik tidak memperoleh batas KKM adalah dengan melaksanakan remedial berupa ujian ulang, dan penugasan. Namun jika peserta didik tidak juga memperoleh ketuntasan belajar, langkah terakhir yang dilakukan guru adalah mengangkat nilai peserta didik agar tetap mencapai KKM.

\section{Daftar Pustaka}

Daryanto, Raharjo.(2012). Model Pembelajaran Inovatif. Yogyakarta: Gaila Media

Depdiknas.(2003). Model Penyelenggaran Sekolah Kategori Mandiri/Sekolah Standar Nasional. Jakarta: Direktorat Pembinaan Sekolah Menengah Atas.Ditjen Pendidikan Dasar dan Menengah

Hayati, Rifda.(2012). Dampak Penetapan Kriteria Ketuntasan Minimal Terhadap Sistem Pembelajaran di SMA N 2 Solok. Padang: Skripsi FIS UNP

Keraf, Gory. (1994). Komposisi. Jakarta: Ikrar Mandiriabadi

Lestari, Pina. Analisis terhadap Masalah yang Dialami Siswa yang Tidak Mencapai Kriteria Ketuntasan Minimal. Padang: Skripsi FIP UNP

Jurnal Socius Vol. 5, No.1, Th. 2018

ISSN: Online 2442-8663 - Print 2356-4180 
Maleong, J Lexy. (2005). Metodologi Penelitian Kualitatif. Bandung: Remaja Rosdakarya

Badan Pengembangan Sumber Daya Manusia Pendidikan dan Kebudayaan dan Penjamin Mutu Pendidikan (2014). Materi Pelatihan Guru Kurikulum 2013 Tahun 2014. Jakarta: Badan Pengembangan Sumber Daya Manusia Pendidikan dan Kebudayaan dan Penjamin Mutu Pendidikan

Margaretha, Mia. (2012). Hambatan Penetapan Kriteria Ketuntasan Minimal Mata Pelajaran Produktif SMK N 1 Lembah Gumanti. Skripsi, Universitas Negeri Padang

Nasution, S. (2011). Metode Research (Penelitian Ilmiah). Jakarta: Bumi Aksara

Peraturan Mentri Pendidikan dan Kebudayaan No 21 Tahun 2016 tentang Standar Penilaian Pendidikan. Jakarta: Mentri Pendidikan dan Kebudayaan

Ritzer dan Douglas J. Goodsman. (2007). Teori Sosiologi Modern. Jakarta: Kencana

Sanjaya, Wina. 2011. Strategi PembelajaranBerorientasi Standar Proses Pendidikan. Jakarta: Kencana

Saputra, Adi. (2016). Pedoman Penilaian Penilaian Kurikulum 2013 SMA Terbaru. Oase pembelajaran.com (diakses tanggal 19 Maret 2017)

Sitorus, Felix. (2001). Pendidikan Kualitaif. Bogor: Kelompok Dokumentasi Ilmu Sosial

Soekanto, Soerjono. (2012). Sosiologi Suatu Pengantar. Jakarta: Raja Grafindo Persada

Sudrajat, Ahmad. (2008). Pembelajaran Remedial. Wordpres. Com (diakses tanggal 11 Maret 2017)

Sugiono. (2009). Metode Penelitian Tindakan. Bandung: Alfabeta

Suwandi dan Basrowi. (2008). Memahami Penelitian Kualitatif. Jakarta: Rineka Cipta

Upe. Ambo. (2010). Tradisi Aliran dalam Sosiologi. Jakarta: Raja Grafindo Persada 